\title{
PART PERFORMANCE SUBSEQUENT TO DISAVOWAL OF AN ORAL AGREEMENT FOR THE SALE OF GOODS*
}

BUSINESSMEN's oral agreements for the sale of goods of substantial value can be held legally unenforceable under the Statute of Frauds. ${ }^{1}$ In bargains involving large amounts but simple terms, the parties' established pattern of personal dealing may give rise to unwritten agreements.2 Swift, direct,

*John Thallon \& Co. v. Edsil Trading Corp., 302 N.Y. 390, 98 N.E. $2 d 572$ (1951).

1. "A contract to sell or a sale of any goods or choses in action of the value of five hundred dollars or upwards shall not be enforceable by action unless . . . some note or memorandum in writing of the contract or sale be signed by the party to be charged or his agent in that behalf." UNIForar Sales ACT § 4(1) (1906).

The Uniform Sales Act version has been adopted by 34 states, the District of Columbia, Hawaii and Alaska. 1 Wrisston, Sales iii (3d ed. 1948). Seven additional states have similar provisions. However, Kansas, Louisiana, New Mexico, North Carolina, Texas, Virginia and West Virginia have no corresponding statutory provisions. See 2 Corbin, Contracts $\$ 467$ et seq. (1951); 1 Wruliston, Sales $\$ \S 51$, 52 (3d ed. 1948). The proposed Uniform Commercial Code, Proposed Final Draft No. 2 (1951) retains most of the Statute of Frauds treatment of the Uniform Sales Act. See note 17 infra and text for discussion of the changes proposed by the Code.

The theory behind the original Statute of Frauds, 29 CEAs. 2 c. 3 (1677) was that a writing requirement would preclude the fraud that results from collusion and subornation of perjured testimony. See, e.g., 2 ConBrn Covmricts $\$ 275$ (1951); Rabel, The Statute of Frauds and Comparatice Legal History. 63 L.Q. Rev. 174, 181 (1947); Comment, 13 CoRs. L.Q. 303, 305 (1928). Application of the Statute todiay, when these policies are no longer so urgent, has caused widespread and emphatic opposition from most legal commentators. The statute has been freely criticized as "promoter of frauds" because it often may defeat the enforcement of honest promises. For typical attitudes, see Stephen \& Pollock, Section Seventeen of the Statute of Frauds, 1 L Q. REr. 1 (18s5); Burdick, A Statute For Promoting Fraud, 16 Cor. L. Kev. 273 (1916); Willis, The Statute of Frands-A Legal Anachronisn, 3 Inn. L. J. 427 (1923). See also English Law Revision Committee, Sixth Interim Report, The Statute of Frands and the Doctrine of Consideration, 15 CAN. B. REv. 585 (1937). For almost the sole contemporary academic support of the Statute, see Llewerlyn, Cases and Miateranls on Sales 917-18 (1930). Compare, "[T]ransactions . . . would do well to be in writing, and . . . a rule which presses in that direction presses well," ibid., and, "[T] better adapted to our needs than when it first was passed.... "[II]udern developments of business ... confirm the policy of the statute." Llewellyn, What Price Contract-An Essay in Perspective, 40 YALE L. J. 704, 747 (1931), with, "[A]ssertions of the beneficence of the Statute ... usually betray their own superficiality.... [T] he statutory provisions should be wholly abandoned because they increase litigation, greatly promute dishonest repudiation, and do not greatly aid our judicial system to frustrate fraud and perjury." Corbin, The Uniform Commercial Code-Sales; Should It Be Evacted? 59 Yale L.J. 821, 831 n.7, 832 (1950).

2. See Ozier v. Haines, 103 N.E.2d 485 (IIl. 1952) (5,000 bushels of corn). See also cases in note 3 infra. The business frequency of oral agreements cannot be ascertained with any accuracy. Data on the actual conduct of business men is practically nonexistent. And even the available data fail to correlate business conduct with legal requirements. Nevertheless, that some business men do make oral agreements is evidenced 
telephonic arrangements may be convenient, and relied on by the parties without subsequent written confirmations. ${ }^{3}$ But if one party refuses to go through with his part of the bargain, his pleading the lack of writing as a statutory defense to an action may permit him to defeat with legal impunity the other party's normal business expectations. ${ }^{4}$

The Statute, however, provides certain means for its own avoidance." Under the part performance doctrine, the most familiar of the Statute's exceptions, a plaintiff can hold the breaching party to the full extent of his promise if a part of the goods covered by the oral contract was taken or paid for. ${ }^{6}$ And courts, seeking to make oral commitments binding, have liberally applied the part performance exception. ${ }^{7}$ Thus the New York Court

by the fact that litigation over the Statute of Frauds is not uncommon. The $5 \mathrm{TH}$ DEc. DiG. (1936-1946) lists about 2750 cases under the Statute of Frauds section. Of these, nearly 1200 were concerned with sale of goods. Typically, an oral agreement is sued upon and resisted by the statutory defense of no writing. 21 WEST'S 5Tr DEC. DiG. 18221988 (1947). See also Llewellyn, Cases and Materials on Sales 910 (1930).

For a strong industry recommendation that written contracts always be used because they provide the only adequate protection against breach, see TExTiLe Disturuutors Bulletin No. 686, Dec. 5, 1946, p. 1, cited in Comment, Remedies for Total Brcach of Contract tunder the Uniform Revised Sales Act, 57 YALE L.J. 1360 n.1 (1948).

3. See, e.g., Castle v. Swift \& Co., 132 Md. 631, 104 Atl. 187 (1918) (telephonle purchase of 200 cases of eggs) ; Whiteneck \& Bassett v. Weaver, 139 Okla. 88, 281 Pac. 293 (1929) (telephonic sale of 100 bales of 'cotton) ; Goodwin v. Mariners' Savings Bank, 99 Conn. 169, 121 Atl. 172 (1923) (telephonic sale of 50 shares of stock).

4. It has been said that as a matter of business practice, the Statute of Frauds defense is invoked only when a party needs a technical escape from unconscionable contract terms. Social pressure of the business community may prevent invocation of the technical defense to defeat a "fair" oral agreement. Rabel, The Statutc of Frands and Comparative Legal History, 63 L.Q. REv. 174, 187 (1947).

5. "A contract to sell or a sale of any goods or choses in action of the value of five hundred dollars or upward shall not be enforceable by action unless the buycr shall accept part of the goods or choses in action so contracted to be sold or sold, and actually receive the same, or give something in earnest to bind the contract, or in part payment. . . " UNIFORM SALES ACT § 4(1) (1906).

Earnest, as distinguished from part payment, is seldom given today. 1 Wirusron, SAles $\$ 97$ (3d ed. 1948). For a discussion of part payment generally, sec id. at $\S 98$ et seq.; 2 Corbin, Contracts $\$ 496$ (1951).

"The fact that the statute thus expressly provided an easy method for its own avoid. ance is strong evidence of the lack of necessity for any such statute." Corbin, The Uniform Conmercial Code-Sales; Should it be Enacted? 59 YALE L. J. 821, 831 n.7 (1950).

6. See note 5 supra for the statutory provision. Acceptance and actual receipt are imposed as a dual requirement. E.g., H. W. Myers \& Son v. Felopulos, 116 Vt. 364, 76 A.2d 552 (1950). They need not be simultaneous, nor occur at the time of the agreement, but the two acts must "refer to the whole contract." See 2 Corsin, CoNTRACTS § 482 (1951). "The buyer may reject the goods though he has previously accepted them, provided he has not as yet received them." 1 Williston, Sales $\& 82$ (3d ed. 1948) (emphasis added).

7. "In innumerable cases, the courts have invented devices by which 'to take a case out of the statute.' " 2 Corrsn, Contracts § 826 (1951). See, e.g., Whiteneck \& Bassett 
of Appeals in John Thallon \& Co v. Edsil Trading Corp. ${ }^{8}$ recently held that defendant's partial performance even after he had unequivocally repudiated the oral bargain bound him to his full obligation under the larger agreement. ${ }^{\circ}$

The parties had agreed orally to the purchase and sale of a quantity of lard, shipments to be made on written confirmations signed by the buyer. When he had confirmed 240,000 pounds, the defendant buyer refused to confirm more. ${ }^{10}$ The confirmed quantity was delivered and received one month later. Plaintiff seller, alleging an oral agreement for the purchase of 440,000 pounds, denied by the buyer, pleaded the buyer's part performance by acceptance and receipt of 240,000 pounds as overcoming his defense under the Statute of Frauds. ${ }^{11}$ When the court upheld a finding that the original oral agreement was actually for 440,000 pounds, it concluded that the buyer had partially performed the larger agreement within the meaning of the Statute's part performance exception and held him to his oral promise to take 440,000 pounds. ${ }^{12}$

In general, holding a party to the full extent of his obligations, whether written or oral, may well accord with the mores of the business community. ${ }^{13}$

v. Weaver, 139 Okla. 88, 281 Pac. 293 (1929) (plaintiff buyer's acceptance of tagged samples held sufficient partial acceptance and receipt of goods); Black Beauty Coal Co. v. Cohen, 267 Mass. 98, 165 N.E. 878 (1929) (defendant buyer's offer to resell held sufficient "acceptance" of goods); Harlan v. Carney, 219 Mich. 539, 189 N.W. 27 (1922) (inspection of goods and expression of satisfaction therewith by buyer held sufficient "acceptance").

8. 302 N.Y. 390, 98 N.E. 2d 572 (1951). Desmond, J., wrote the court's opinion, in which Conway, Dye and Froessel, J. J., joined. A separate concurring opinion was written by Froessel, J., joined by Conway, Desmond and Dye, J.J.; Fuld, J., dissented along with Loughran, C. J., and Lewis, J.

9. There is some authority for the view that the doctrine only applies when performance precedes repudiation. "[I]f the buyer when taking part declines to take more, the statute is not satisfied." 1 Wuliston, Sales $\$ 94$ (3d ed. 1948). Cf. Atherton v. Newhall, 123 Mass. 141 (1877) (buyer liable only for amount received before his "repudiation"). See also Gordon v. Witty, 198 App. Div. 333, 336, 190 N.Y. Supp. 381, 382 (1st Dep't 1921) (acceptance must be "prior to revocation") ; Good v. Curtis, 31 How. Pr. 4, 11 (N.Y. Sup. Ct. 18\&6) (buyer liable only while contract remains "unrevoled"); Adams v. King, 68 Okla. 190, 192, 170 Pac. 912 (1918) (buyer liable only on goods accepted prior to his "abrogation").

10. The defendant had signed two written confirmation orders for 240,000 pounds and retained a third confirmation order for 200,000 pounds. When the price of lard dropped substantially, defendant "announced ... that [he] would not take more than 240,000 pounds, the quantity for which [he] had signed confirmations." 302 N.Y. 390, 395, 98 N.E. $2 d$ 572, 576 (1951).

11. Brief for Plaintiff-Appellee, pp. 15-18, John Thallon \& Co. v. Edsil Trading Corp., 302 N.Y. 390,98 N.E.2d 572 (1951).

12. The partial performance consisted in the buyer's subsequent acceptance and receipt, not in his confirmation of the lesser quantity. 302 N.Y. 390, 393, 98 N.E.2d 572, 573 (1951).

13. The primary objective of the law of contracts is the performance of considered promises. See Sharp, Pacta Sunt Servanda, 41 CoL. L. REv. 783, 784 (1941); Fuller \& Perdue, The Reliance Interest in Contract Damages, 46 Y MLE L.J. 52, 62 (1936). And see note 4 sispra. 
But the parties in the Thallon case dealt in the shadow of the Statute of Frauds. If the buyer after repudiating the oral agreement had done nothing more, he could have escaped legal liability because the Statute's requirements were not satisfied. ${ }^{14}$ And his unequivocal repudiation, relying on his immunity under the Statute of Frauds, doubtless scaled down the seller's business expectations. Moreover, having had advance warning beforc shipment of any goods, the seller had at least three alternatives : he could have decided to abandon the entire deal without legal recourse; he could have attempted to force the buyer to execute a writing that would satisfy the Statute and obligate him for the entire agreement; or he could have settled for the sale of a smaller amount instead of the amount under the larger oral contract. Instead he delivered in part, sat back, gambled on a lawsuit, and won.

As an inroad on the writing requirement of the Statute of Frauds, the Thallon decision will not cut deep. Warned by the holding, future buyers will be more circumspect. They may refuse to perform any part of an oral contract which they could escape completely via the Statute of Frauds. ${ }^{10}$ Or they may carefully insist that the seller agree to formal rescission of the larger oral agreement before contracting with him anew for lesser amounts. ${ }^{10}$ Thus the full liability imposed by Thallon can be readily finessed.

14. "Had defendant refused to take any of the lard . . plaintiff would have had 10 case." 302 N.Y. 390, 395, 98 N.E.2d 572, 575 (1951) (concurring opinion).

The cases are legion where a simple oral contract is sued upon and where the plaintiff's sole proof is his testimony on the parol agreement. The courts are unanimous in holding these cases unenforceable under the Statute of Frauds. See, c.g., H. W. Myers \& Son v. Felopulos, 116 Vt. 364, 76 A.2d 552 (1950); Webster v. Condon, 248 Mass. 269, 142 N.E. 777 (1924); In Steiner v. Am. Alcohol Co., 181 App. Div. 309, 168 N.Y. Supp. 739 (2d Dep't 1918) the contract was held unenforceable for lack of a writing even though the defendant's fraud caused the omission of the writing.

15. If the Thallon decision is effective, few buyers would regard part performance as worth the risk of a liability for more than was taken. In some situations, the seller will thus be deprived of the entire benefit of his original bargain. At least partial performance may salvage a portion of the business deal.

16. Rescission means a mutual agreement by the parties to an existing contract to discharge and terminate their duties under it. Courts require formality and proof of a mutual and uncoerced desire to rescind an existing agreement, although such assent to the rescission may be implied. But if any contractual right to further performance under the contract continues to exist, there has been no complete rescission. "Just as in the case of the formation of a contract, an operative agreement of rescission can be made tacitly as well as expressly. Also it is possible to make a valid rescission even though it is only one of the parties who has an active desire for it and even though he is threatening a breach of his contract. If an offer of rescission is made under such circumstances, an acceptance of the offer completes the discharge of the existing contracts, cvell though the acceptance is accompanied by feelings of regret and dissatisfaction." 5 Corwin, ConTracts § 1236 (1951).

The unenforceability of a contract under the Statute of Frauds might impair its status as an "existing contract," thus making it incapable of rescission. But the prevailing English and American view is that the Statute affects only the "enforceability" but not the 
On the other hand, the proposed Uniform Revised Sales Act, by a blanket restriction of liability under the part performance exception, goes too far. ${ }^{17}$ By the terms of the Act, oral contracts otherwise valid are enforceable only "in respect to goods for which payment has been made or accepted or which have been received and accepted." 18 Since no specific language differentiates partial performance which has preceded disavowal of the agreement from such performance subsequent to disavowal, both are probably intended to be treated alike. But certainly where partial performance has preceded repudiation, the traditional part performance exception imposing full contractual liability secures parties in their business expectations. Such partial performance is made at a time when full performance, not breach, is contemplated by at least one of the parties, and probably reinforces his com-

"validity" of the contract-it is a "limitation of judicial authority to afford a remedy." Safe Deposit Co. v. Diamond Coal Co., $234 \mathrm{~Pa}$. 100, 83 Atl. 54 (1912). Thus, the contraet "exists" under the Statute, albeit without remedy. For full discussion, see 1 WiLusso:, Sales $\$ 71 \mathrm{a}$ (3d ed. 1948).

But the party who seeks a new contract must take care not to make any written proposals to the other party which refer to the original agreement. For courts liberally construe any writing by the party to be charged as a sufficient memorandum to satisfy the Statute of Frauds. See, e.g., Sennot v. Cobb's Pedigreed Chicks, 324 Mass. 9, 84 N.E.2d 466 (1949) (letter of repudiation); Jacobson v. Hendricks, $\$ 3$ Conn. 120, 75 Atl. 85 (1910) (letter referring to the agreement, though written to breaching party's own agent); Gall v. Brashier, 169 F.2d 704 (10th Cir. 1948) (written reference to agreement retained by party to be charged). Moreover, despite the literal wording of the statute, the memorandum need only to be written, not signed. Pearlberg v. Levisohn, 112 Mlise. 95, 182 N.Y. Supp. 615 (Sup. Ct. 1920). For general discussion, see 2 Cosprs, Co:tructs $\S 498$ et seq. (1951); 6 Williston. Contricts $\$ 1820$ et seq. (rev. ed. 1938).

17. "A contract which does not satisfy the requirements of writing but which is valid in other respects is enforceable ... (c) with respect to goods for which payment has been made and accepted or which have been received and accepted." Usurrow Co:sserectal Code, Proposed Final Draft No. 2 (1951 draft) $\$ 2-201$ (3). This revision of the Uniform Sales Act was prompted by conviction that some perjury would thereby be prevented. "No doubt this limitation was made because it has always been possible for a handy liar to testify orally that he paid a dollar on account or delivered one of the shoestrings, thus making it easy to defeat the real purpose of the statute" Corbin, The Unsforn Commercial Code-Sales; Should It Be Enacted? 59 YALE L.J. \$31, 831 (1950).

For the statements of opponents of this provision of the Code, see Williston, The Low of Sales in The Proposed Uniform Commercial Code, 63 HARv. L. Rev. 561, 575.6 (1950) ; Corbin, supra, at 831 n.7. The latter writer, however, is a supporter of the Code generally.

18. See note 17 supra. The effect of the Code provision is a partial repeal of the part performance doctrine. However, the doctrine is not scuttled in its entirety. Under the Code provision, the price of the goods taken in part performance is based on the agreed upon price in the oral agreement. And the court is directed to apportion that price to the amount taken. Comments to Uniform Revised Sales Act \& 201 (Spring 1950 draft). If the doctrine were fully repealed, the price of the goods taken would be their fair market value only. See Boone v. Coe, 153 Ky. 233, 154 S.W. 900 (1913). For criticism of this feature of the Code, see Corbin, stpra note 17, at 831 n.7 ("a true apportionment of the goods or the price can not be made without first proving the terms of the contract, and having proved them the contract should be enforced in full"). 
mercial anticipations that the agreement will be fully carried out. ${ }^{10}$ The part performance exception here prevents the interposition of the no-writing technicality from defeating the business expectation of another contracting party. ${ }^{20}$ The Revised Act's limitation of liability in this situation unwarrantedly deprives parties to oral agreements of protection they had under prior law.

However, the Act as applied to disavowal of the oral agreement preceding partial performance probably accords with business reality. Such disavowal at an early moment puts all parties on notice that the agreement is not to be performed. And the Statute of Frauds, by immunizing the disavowal, compels the other contracting party to scale down his anticipations. As a result, he may go through with part of the original oral agreement, rather then exercise his business alternative of securing full performance or none at all. This conduct is functionally equivalent to his bargained-for acquiescence in a formal recission of the larger oral agreement, followed by a new contract for the lesser amount. ${ }^{21}$ Thus the Act, in effect, short-circuits the necessity for a prior formal rescission of the oral agreement, and thus eliminates a legal requirement that would merely formalize a tacit bargain.

19. Cf. "The part performance must be clearly evidential of the existence of a contract-it must be such as would not ordinarily have taken place in the absence of a contract, and therefore is not reasonably explicable on some other grounds." 2 Conow, ConTRACTS $\S 430$ (1951). Some courts are explicit in demanding that the defendant intend to complete a larger contract before holding him to that larger amount. It must appear that the buyer "acknowledged the existence of the alleged contract and that what was done ... was done solely with a view to its performance." Howland v. Iron Fircman Mfg. Co., 188 Ore. 230, 323, 215 P.2d 380, 388 (1950). See also Golden Eagle Milling Co. v. Old Homestead Bakery, 59 Cal. App. 541, 211 Pac. 56 (1922) ; Brister \& Koester Lumber Corp. v. American Lumber Corp., 356 Pa. 33, 50 A.2d 672 (1947).

20. The expansion of the doctrine has probably been due to the desire of the courts to avoid such frustration of honest agreements. See note 7 supra.

21. See note 16 supra. Ordinarily it is possible for parties to mutually rescind an agreement and in the same transaction enter into a new one. Schwartzreich v. BaumanBasch, Inc. 231 N.Y. 196, 131 N.E. 887 (1921). Though the issue was not discussed in the Thallon case, a persuasive case could be made that this was the nature of the transaction involved. The seller certainly understood at the time of the repudiation that the buyer was terminating his obligation; when the seller nevertheless tendered the lesser quantity of lard as per the requests of the buyer, he can be said to have impliedly accepted a new agreement to substitute for the old. 